\title{
Memories of Prof. Geoffrey Burnstock
}

\author{
Nawazish-i-Husain Syed ${ }^{1,2}$
}

Received: 22 January 2021 / Accepted: 26 January 2021 / Published online: 3 March 2021

(C) The Author(s), under exclusive licence to Springer Nature B.V. part of Springer Nature 2021

I first met Geoffrey Burnstock, when undertaking my $\mathrm{PhD}$ studies, with Charles Kennedy at the University of Strathclyde, Glasgow, Scotland. Geoff visited the University of Glasgow to deliver a wide-ranging and captivating lecture in which he discussed, among other things, the origin and development of our knowledge and understanding of purinergic receptors and the most promising therapeutic areas in which they could be targeted in future. After the talk, Prof. Burnstock met us with a smile as Charles introduced us as his $\mathrm{PhD}$ research students.

The next time I met Prof. Burnstock was at the Purines 2008 meeting in Copenhagen, Denmark, and I was presenting our data on P2X receptors in pulmonary arteries. Geoff's talk, as a plenary speaker, was intriguing and interesting, as he discussed the advent of purinergic theory, its receptors, and signalling pathways in a most articulate way and highlighted the most recent advances in this field. His presence as a leader of the whole fraternity of purinergic scientists made us feel proud to be connected with the field and for which the future was looking bright. Furthermore, during our stay in Copenhagen, intermittent interactions with Geoff inspired us greatly. In several face-to-face interactions, I immediately realized that his towering figure did not exclude anyone from his sphere of ambience, while his personality and enthusiasm

Nawazish-i-Husain Syed

nawazish.pharmacy@pu.edu.pk; snihusain@yahoo.com

1 Pharmacology Department, Punjab University College of Pharmacy, University of the Punjab, Lahore 54000, Pakistan

2 Faculty of Health Sciences, University of the Punjab, New Campus, Lahore 54000, Pakistan inspired and motivated us to do more in the field and to try to raise the bar of excellence even further up.

I was also present when he delivered the Gaddum Prize lecture at the British Pharmacological Society's esteemed winter meeting in London, 2011. Here, he was again quite optimistic about what the future holds for purinergic signalling and its therapeutic outcomes. His talk as the leader of the purinergic field kept everyone hooked throughout the amazing journey of purinergic signalling and how the purinergic theory contributed to a better understanding of physiological and pathophysiological phenomena.

With his departure from the mortal world, he leaves behind a firmly established field of research due to the impression of his own work, his encouragement to young researchers, and the creation of interest in a wide range of scientific groups. Prof. Burnstock shall always be holding the center stage wherever purinergic signalling is discussed. It is not, of course, the end of an era of purinergic signalling, rather a beginning of a harvest of molecules of therapeutic value, which will relieve the suffering of afflicted people on this planet. Farewell, Prof. Burnstock for the journey to an unknown destination, with peace and serenity.

\section{Compliance with ethical standards}

Ethical approval This article does not contain any studies with human participants or animals performed by any of the authors.

Conflicts of interest Nawazish-i-Husain Syed declares that he/she has no conflict of interest.

Publisher's note Springer Nature remains neutral with regard to jurisdictional claims in published maps and institutional affiliations. 